QUADERNS DE FILOSOFIA VOL. II NÚM. I (2015): 95-I I 3

ISSN: 234I-I4I 4 DOI: IO.7203/QFIA.2.I.4I 40

Josep Artés GIL

Universitat de València

\title{
Foucault, trenta anys després: vigència i potencialitats de la microfísica del poder ${ }^{1}$
}

Recibido: 22/9/14. Aceptado: 25/11/14

Resum: La microfísica del poder — de la qual Michel Foucault esdevé el principal exponent- emergeix com un efecte del panorama que segueix el Maig del 68, en el qual sorgeix un cicle de noves lluites centrades en el reconeixement i el desenvolupament de nous tipus de subjectivitat. Ara que han passat trenta anys des de la mort de l'autor, defensaré la necessitat d'aplicar la microfísica del poder a una realitat que ja no pot respondre a unes anàlisis fonamentades en paràmetres estrictament econòmics i que demanda, en canvi, eixamplar el camp de visió per incloure-hi el paper que juga el poder en la producció de les subjectivitats.

Abstract: Michel Foucault is the main exponent of microphysics of power, that emerges as an effect of the scene following the May 68, in which there is a new cycle of struggles focused on the recognition and development of new types of subjectivity. On the thirtieth anniversary of the author's death, I will defend the need to aply microphysics of power to a reality that we can not respond to analyzes based on strictly economic parameters and demand, however, widen the field of vision to include in it the role of power in the production of subjectivities.

${ }^{1}$ Aquest article s'ha nodrit, tant en la forma com en el contingut, dels comentaris i suggeriments de Miquel A. Martínez i Joan B. Llinares. Els errors que hi puguen romandre són de la meua exclusiva responsabilitat. Per una altra banda, per la falta de literatura en català sobre la qüestió, les cites apareixen traduïdes lliurement de les edicions en castellà. Em faig responsable també, per tant, de qualsevol incorrecció que hi aparega al respecte. 
Paraules clau: anatomopolítica, biopolítica, causa immanent, diagrama, disciplina, dispositiu, micropolítica, neoliberalisme, poder, sobirania, subjectivitat.

Keywords: anatomopolitics, biopolitics, device, diagram, discipline, immanent cause, micropolitics, neoliberalism, power, sovereignty, subjectivity.

INTRODUCCIÓ: L'EIXAMPLAMENT GENEALÒGIC DE L'ARQUEOLOGIA DEL SABER

$\mathrm{F}$ OUCAUlt arriba a la genealogia del poder després d'haver efectuat una exhaustiva arqueologia del saber, en la qual ja concebia el poder com l'encarregat de distribuir en el camp social els règims de visibilitat $i$ d'invisibilitat, per una part, i el règims d'enunciació per l'altra. Amb això, Foucault assenyalava que "entre tècniques de saber i estratègies de poder no existeix exterioritat alguna, fins i tot si posseeixen el seu propi paper específic i s'articulen una amb l'altra, a partir de la seua diferència" (Foucault i 976, 119). En qualsevol cas, Foucault no concebia el poder com una instància oculta que calia desvelar, sinó precisament com la condició de possibilitat dels diferents sabers que circulen al llarg d'un marc històric determinat. De fet, va arribar a definir aquests règims com allò que estableix les condicions de possibilitat del seu temps, això és: com un a priori històric. ${ }^{2}$ Per aquesta part, els sabers passaven a ser, ja no l'embolcall d'un poder subjacent, sinó els efectes o la conseqüència d'un poder que els esperona i que afavoreix — $\mathrm{O}$, al contrari, bloqueja — la seua emergència i el seu establiment. A partir d'ací, Foucault focalitza la seua atenció en unes pràctiques no-discursives que, si bé ja hi eren presents a l'etapa arqueològica - com es pot comprovar a la Histoire de la folie à l'âge classique —, no tenien el predomini que presenten a partir de Surveiller et punir. D'aquesta manera, la genealogia es pot entendre com un increment en la profunditat de l'anàlisi de les pràctiques no-discursives que ja hi eren al si de les pròpies pràctiques discursives. De fet, l'anàlisi posa la seua atenció en el mateix segment històric sobre el qual s'havia aplicat l'arqueologia del saber: el que Foucault anomena l'època clàssica, corresponent als segles XVII i XviII. Aquest moment del devenir històric resulta fonamental des de la perspectiva que estem observant, ja que és en aquest context que es produeix l'emergència del diagrama disciplinari.

\footnotetext{
${ }^{2}$ Amb aquest ròtol, pretesament paradoxal, Foucault descriu l'objecte d'anàlisi de la seua arqueologia, que no és altre que les regularitats que sorgeixen de cada saber històric concret, però sempre tenint en compte la contingència, multiplicitat i pluralitat de cadascun d'ells. És a dir: el que pretén l'arqueologia, al remat, és una simple localització i no cap reconducció que ajustaria el saber de cada època a unes regularitats transcendents, ja que açò delataria un intent de reescriure la història des d'un defora, des d'un centre, des d'un més enllà de tarannà eminentment hegelià.
} 


\section{i. Caracterització general Del poder}

A Surveiller et punir, Foucault relata com, a finals del segle XvIII i principis del XIX —més concretament, entre els anys 1760 i 1840 -, es produeix una limitació de l'espectacle punitiu, tot passant de les exhibicions públiques —amb tota la càrrega "terroritzant" que aquestes posseïen — a un emmurallament adreçat a ocultar tot l'espectre de dinàmiques punitives. Així s'aconseguia que aquestes pràctiques foren més discretes, tenint en compte que els càstigs de tipus espectacular — sobretot en el cas de l'execució públi$\mathrm{ca}$ - igualaven o, fins i tot, superaven en cruesa els crims que es tractaven de condemnar. Amb aquest moviment, la justícia fa del càstig ja no una oportunitat per efectuar una demostració histriònica del seu poder, sinó, al contrari, una oportunitat per dotar d'un tarannà moderat, però també més efectiu, les seues pràctiques punitives; és a dir, fa aparèixer aquestes pràctiques —en la seua no-aparició- com una obligació que cal complir inevitablement. D'aquesta manera, la justícia fa del càstig una responsabilitat que ha de portar a terme de manera obligatòria — fins i tot amb una certa vergonya-, fins acabar delegant, en els seus intents per separar-se'n, en un dispositiu annex. Aquest dispositiu no és altre que el de la presó, amb la qual es passa de l'espasme de mort efectuat pel botxí, a una suspensió dels drets perllongada en el temps sota l'assessorament d'una munió de tècnics — "els vigilants, els metges, els capellans, els psiquiatres, els psicòlegs, els educadors” (Foucault I975, 19)—. Amb aquesta eliminació de la figura del botxí, es fa palesa no només la pretensió de discreció, sinó també un nou objectiu: ja no es tracta de garantir la mort, sinó la reinserció del condemnat en la societat; és a dir, la seua requalificació com a subjecte de dret a través d'una coerció sostinguda dels seus hàbits i els seus comportaments.

Aquest és el pas que s'efectua amb la reforma penal del segle XviII, mitjançant la qual el càstig s'atenua pel que fa a la seua expressió immediata. A canvi, però, d'una expansió espacial — de la plaça pública a una multiplicitat de centres penitenciaris - i temporal — de l'esdeveniment dràstic a la continuïtat constant- A partir d'aquesta nova distribució del poder, Foucault es veu menat a eixamplar la seua anàlisi fins localitzar les relacions de poder — definides per la seua capil-laritat — en totes aquelles relacions que resulten bàsiques per configurar la societat. Tot i això, aquest moviment que es produeix envers les tècniques punitives, no comporta la supressió de les pràctiques associades a la sobirania —efectuades també directament sobre el cos-, la pervivència de les quals es pot trobar, fins i tot, en l'actualitat, en càstigs com ara la pena de mort, els treballs forçats, l'austeritat alimentària, la privació sexual, les tortures o la disposició angoixant de les celles en els 
centres carceraris. ${ }^{3}$ Alguns elements del diagrama de la sobirania — entenent el diagrama com la disposició general de les relacions de forces espargides arreu del camp social — s'insereixen, per tant, al si del diagrama disciplinari, però ambdós mostren un tret en comú: delimitar el cos com a principal superfície d'inscripció del poder. És per aquesta raó, que les relacions de poder en el seu vessant disciplinari es descriuen, sovint, com una anatomopolitica:

Per poder disciplinari no entenc cap altra cosa que una determinada forma d'alguna manera terminal, capilllar, de poder; un últim relé, una determinada modalitat per la qual el poder polític, els poders en general, venen, en l'últim nivell, a tocar els cossos, els mosseguen, es fan càrrec dels gestos, dels comportaments, dels hàbits, de les paraules, de la manera en la qual tots aquestos poders es concentren cap avall fins tocar els cossos individuals mateixos; treballen, modifiquen, dirigeixen allò que Servan anomenava les "fibres mòrbides del cervell". Dit d'una altra manera, jo crec que el poder disciplinari és una determinada modalitat, molt específica de la nostra societat, d'allò que es podria anomenar el contacte sinàptic cos-poder (Foucault 2005, 42)

L'aplicació d'aquest poder punitiu sobre el cos té com a objectiu la producció d'una subjectivitat concreta. Això serveix com a punt de partida a Foucault per enunciar una de les seues tesis més importants: el subjecte no és aquell sobre el qual s'aplica el poder —o, traduït en termes teològics, aquell qui es mereix el càstig per la seua culpa ancestral—, ${ }^{4}$ sinó que és, més aviat, el resultat d'aquesta aplicació, l'efecte d'aquest poder:

No hi ha que concebre l'individu com una espècie de nucli elemental, àtom primitiu, matèria múltiple i inert sobre la qual s’aplica i contra la qual colpeja el poder, que sotmet els individus o els trenca. En realitat, un dels efectes primers del poder és precisament fer que un cos, uns gestos, uns discursos, uns desitjos, s'identifiquen i consitueixquen com individus (...). L'individu no és qui està enfront del poder; és, crec, un dels seus efectes primers (Foucault 2008A, 38)

3 "[Foucault] es va fer immediatament sensible a l'enorme diferència entre l'estatut teòric i jurídic de la carcel, la carcel com a privació de llibertat, i la pràctica de la carcel, que és quelcom completament distint, donat que no es limita a privar de llibertat a algú, la qual cosa ja és molt, sinó que a més hi afegeix tot el sistema de les humiliacions, tot el sistema que anul.la les persones i que no forma part de la privació de llibertat" (Deleuze 2007, 249).

4 "Realitat històrica d'aquesta ànima que, a diferència de l'ànima representada per la teologia cristiana, no neix culpable i punible, sinó que naix més bé de procediments de càstig, de vigilància, de pena i coacció" (Foucault 1975, 36). 
Arribats a aquest punt, Foucault es disposa a extrapolar les relacions de poder de les institucions disciplinàries a tota la societat, per comprovar com es dóna la producció de subjectivitat a partir d'aquesta dinàmica de forces espargida per tot arreu. Aquestes relacions de poder presenten un seguit de característiques - tot fent palesa, en la majoria de casos, les diferències pel que fa a l'anàlisi marxista-:

1. El poder "s'exerceix més que no es posseeix" (Foucault 2008A, 38), està contínuament en circulació. En aquest sentit, el poder és immanent, intern al propi cos social en el qual circula, més que no transcendent $\mathrm{i}$ separat d'aquell, com ocorre, per exemple en la concepció maquiavèl.lica. ${ }^{5}$ La concepció del poder com una cosa que només pot ser posseïda, per exemple, per una classe social o per un rei sota la forma del ceptre i que, per tant, es pot cedir o prendre - per una altra classe social o per un altre rei-introduiria un caràcter rígid a l'anàlisi. Un poder dinàmic necessita, en canvi, una anàlisi igualment dinàmica. Així, la possessió del poder per una classe social respon a una estratègia que fa cristal.litzar les relacions de poder esteses arreu del camp social, concentrades principalment al voltant de les estructures estatals i legals que, en qualsevol cas, sempre anirien per darrere de les relacions de poder capillars i immanents al camp social, i no anteriors, com suposa aquella visió segons la qual aquestes relacions de poder apareixen com un seguit de representacions, repeticions $\mathrm{i}$ reflexos derivats d'"un punt central, (...) un focus únic de sobirania del qual irradiarien formes derivades i descendents" (Foucault 2006, 115-6). Aquesta cristal-lització, per tant, és sempre l'efecte, i mai no la causa, de les relacions de poder, de la mateixa forma que el subjecte, com hem vist, és l'efecte de les relacions de poder exercides sobre la superfície del cos. ${ }^{6}$

2. El poder no és únicament una cosa imposada per aquells que el posseeixen sobre aquells que no el posseeixen: per exemple, quelcom que l'Estat imposa sobre els ciutadans. En la mesura que el poder circula de manera reticular, cada relació de poder ha de constar de dos pols que es veuen travessats per aquest, cadascun dels quals és susceptible tant de patir-lo com d'exercir-lo. ${ }^{7}$ Tot està revestit pel poder, fins $\mathrm{i}$ tot — $\mathrm{i}$, especialment— les anomenades classes

5 "El príncep de Maquiavel rep el seu principat, siga per herència, siga per adquisició, siga per conquesta; de totes formes, no forma part d'aquell, n'és exterior. No hi ha pertinença fonamental, essencial, natural i jurídica entre el príncep i el seu principat. Exterioritat, transcendència del príncep" (Foucault 2006, 115-6).

${ }^{6}$ Aquesta característica suggereix l'abandó, segons Deleuze, del postulat de la propietat (del poder) (Deleuze i 986, 36).

7 "Cada força té un poder d'afectar (altres forces) i de ser afectada (també per altres forces), de manera que cada força implica unes relacions de poder; i tot camp de forces distribueix les forces en funció d'aquestes relacions i dels seus canvis" (Deleuze i 986, 86). 
oprimides. En aquest sentit, la immanència a la qual sotmet Foucault l'anàlisi del poder, situa la resistència dins l'àmbit del propi poder, com un pol de les seues múltiples relacions: "on hi ha poder hi ha resistència $\mathrm{i}$, no obstant això (o millor: precisament per això), aquesta mai no està en posició d'exterioritat respecte del poder" (Foucault 1976, 116). ${ }^{8}$ Cal desprendre's, per tant, de la imatge del poder com eixa mola freda i feixuga de la qual cal desempallegarse (imatge perpetuada per diferents teories de molt diversa índole, de Hegel a Reich, tot passant per Freud i Marcuse) (Foucault 2008A, 38). Aquesta concepció negativa és, segons Foucault, bastant ingènua, en la mesura que limita les múltiples i diverses capacitats de dominació del poder, presentant-lo com un exercici sense capacitat d'innovació i condemnat a repetir indefinidament els seus recursos prohibitius. El poder, en canvi, és positiu i productor, produeix més que no prohibeix; al capdavall, té un caràcter molt més creatiu, ric, dinàmic i imprevisible del que van pensar els filòsofs contractualistes $\mathrm{i}$ juristes del segle XviII, que el van enunciar en termes legals en referència a la institució monàrquica. ${ }^{9}$ En efecte, si aquesta anàlisi era del tot vàlida per al diagrama de la sobirania, resulta incapaç d'enfrontar-se a les dinàmiques dels diagrames disciplinari i biopolític. Com assenyala Foucault,

és precís desmarcar-se dels paramarxistes, com ara Marcuse, que donen a la noció de repressió un paper exagerat, ja que si el poder no tinguera per funció més que reprimir, si no treballara més que segons el mode de la censura, de

${ }^{8}$ Aquesta característica acaba amb el que Deleuze anomena el postulat de la modalitat, segons el qual "el poder actuaria mitjançant la violència o a través de la ideologia, adés reprimiria, adés enganyaria o posaria als caps una creença; adés policia, adés propaganda" (Deleuze i 986, 39). Pel que fa a la resistència, Foucault no només la concep com coextensiva al poder, sinó que arriba a considerar-la, fins i tot, condició de possibilitat d'aquest: "Les relacions de poder susciten necessàriament, reclamen a cada instant, obrin la possibilitat d'una resistència; perquè hi ha possibilitat de resistència i resistència real, el poder d'aquell que domina tracta de mantenir-se amb més força (...). El que jo tracte de fer aparéixer és més la lluita perpètua i multiforme que la dominació obscura i estable d'un aparell uniformitzant" (Dits et Écrits III, 407, citat a CASTRO 20 I I). En la mesura en què el poder produeix la seua pròpia resistència, deixa obert un marge de maniobra que permet la possibilitat d'inversió de les seues pròpies relacions. És en aquest sentit en el qual la resistència esdevé condició de possibilitat del poder: sense aquesta, les relacions de poder — estàtiques, estancades, fèrriament falcades — passarien a ser, més bé, relacions de dominació. Altrament dit: la resistència, al definir els "altres pols" de les relacions de poder, proporciona a aquest, precisament, el seu caràcter relacional (sense la resistència, el poder no seria una relació sinó, simplement, una mera imposició): "El caràcter estrictament relacional de les relacions de poder no és possible més que en funció d'una multiplicitat de punts de resistència que exerceixen, a les relacions de poder, el paper d'adversari, de blanc, de suport, de sortint per a una aprehensió" (Giraldo Díaz 2006, 120).

${ }^{9}$ Aquest és, precisament, el que Deleuze anomena el postulat de la legalitat. (Deleuze I986, 40). 
l'exclusió, dels obstacles, de la repressió, a la manera d'un gran super-ego, si no s'exercira més que d'una forma negativa, seria molt fràgil. Si és fort, és degut a que produeix efectes positius a nivell del desig —això comença a saber-se- i també a nivell del saber (Foucault, I 992, 106-7) ${ }^{10}$

3. Les relacions de poder s'estenen en una multiplicitat inabastable arreu del camp social, tot definint "punts innumerables d'enfrontament, focus d'inestabilitat que comporten els seus riscos de conflicte, de lluites i d'inversió almenys transitòria de les relacions de forces (Foucault i 975, 34). Per aquesta raó, no té cap sentit analitzar-les de manera aillada, sinó com una estratègia de conjunt a través de la qual aquesta multiplicitat esdevé una xarxa, un complex diagramàtic —que pot produir, com un dels seues efectes, l'Estat-.

Si a l'etapa arqueològica Foucault es centrava, sobretot, en la descripció del concepte d'episteme, l'objecte d'observació de la genealogia és, al seu torn, el de dispositiu. Aquesta noció funciona, precisament, com a frontissa entre les pràctiques discursives i les pràctiques no-discursives. ${ }^{11}$ Així, es pot definir el dispositiu com un nus o un feix en el qual les relacions de poder entren en relació, precisament, amb altres relacions de poder, així com amb un seguit d'elements completament heterogenis a elles — com ara "discursos, institucions, arquitectura, reglaments, lleis, mesures administratives, enunciats científics, proposicions filosòfiques, morals, filantròpiques, allò dit i allò no-dit»(Castro 20I I). Durant el període disciplinari, per posar un dels exemples més reeixits, aquest concepte pren forma, principalment, a través de l'espai arquitectònic —el dispositiu carcerari—, i de les aglomeracions d'individus, com ara en el cas del dispositiu familiar.

Cal afegir, a més a més, el que Foucault anomena la regla de doble condicionament — descrita per Deleuze com una causa immanent_, segons la qual, per una banda, és el dispositiu el que condiciona les relacions de poder que aglutina al seu si, però per l'altra, a la vegada, és aquest mateix dispositiu el que és condicionat per les relacions de poder que l'han format a l'aglutinarse. D'aquesta manera, la relació causal o de condicionament esdevé biunívoca o immanent, ja que entre el dispositiu i les relacions de poder que el formen es donen una sèrie de causes que s'actualitzen als seus respectius efectes; és a dir: les relacions de causalitat acaben derivant en un conjunt de relacions de reciprocitat. Aquesta regla de condicionament o de causa immanent és també

${ }^{10}$ Quan Foucault diu que "això comença a saber-se" s'està referint, sens dubte, al treball de Deleuze i Guattari a Capitalisme i Esquizofrènia.

${ }^{11}$ De fet, la inclusió de l'arqueologia al si de la genealogia es materialitza en la concepció de l'episteme com un dispositiu més - concretament, com un dispositiu discursiu - (CASTRo 2OII). 
aplicable a la relació causal entre el diagrama i les relacions de poder espargides arreu del camp social. ${ }^{12}$

4. El poder no es pot analitzar únicament en termes econòmics, com es fa en el marxisme a l'analitzar l'extracció de la plusvàlua sobre l'activitat de la força de treball —entenent, per aquesta força de treball, un subjecte definit per avançat, amb la capacitat productiva i la possibilitat de transformar el seu entorn com la seua característica essencial, que és obligat a entrar en una relació d'explotació que l'aliena o el separa de les seues potencialitats efectives (FouCAUlT 2008, 26). ${ }^{13}$ Tampoc no es poden efectuar, aquestes anàlisis, en termes d'unes condicions econòmiques anteriors, que generarien, posteriorment, les relacions de poder. En mots de Foucault, són aquests els termes en els quals s'efectua l'anàlisi marxista de tall acadèmic:

Em sembla que (...) l'anàlisi tradicional en el marxisme universitari (...) presenta un defecte molt greu: el de suposar, en el fons, que el subjecte humà, el subjecte de coneixement, i les formes mateixes de coneixement, estan donades en certa mesura prèviament i definitiva, i que les condicions econòmiques, socials i polítiques d'existència, l'única cosa que fan és dipositar-se o imprimir-se en eixe subjecte definitivament donat (Foucault I999, 170)

12 “¿Què vol dir ací causa immanent? És una causa que s’actualitza en el seu efecte, que s'integra en el seu efecte, que es diferencia en el seu efecte. O més bé, causa immanent és aquella que és actualitzada, integrada i diferenciada pel seu efecte. Existeix, doncs, correlació, pressuposició recíproca entre la causa i l'efecte (...). Si els efectes actualitzen, és perquè les relacions de forces o de poder són només virtuals, potencials, inestables, evanescents, moleculars, i només defineixen possibilitats, probabilitats d'interacció, mentre no entren en un conjunt macroscòpic capaç de donar forma a la seua matèria fluïda i a la seua funció difusa" (Deleuze 1986, 49). Respecte a la regla de doble condicionament en Foucault: "Cap 'focus local', cap 'esquema de transformació" no podria funcionar sense inscriure's al cap i a la fi, per una sèrie d'encadenaments successius, en una estratègia de conjunt. Inversament, cap estratègia no podria assegurar efectes globals si no es recolzara en relacions precises i tènues que li serviren, si no d'aplicació i conseqüència, sí de suport i punt d'ancoratge (...). Cal pensar en el doble condicionament d'una estratègia per l'especificitat de les tàctiques possibles i les tàctiques per l'embolcallament estratègic que les fa funcionar" (Foucault I976, 121).

${ }^{13}$ És en aquest sentit en el qual l'anàlisi foucaultiana de poder aboleix el que Deleuze anomena el postulat de subordinació (del poder a l'economia) (Deleuze i 986, 37-8), comú tant al marxisme com al liberalisme. 
Segons Foucault, la disciplina es compon d'un seguit de "mètodes que permeten el control minuciós de les operacions del cos, que garanteixen la subjecció constant de les seues forces, a les quals imposen una relació de docilitat-utilitat" (Foucault 1975, 141). Aquesta intromissió, aquesta manipulació anatòmica, no s'executa sobre un subjecte predeterminat, sinó que és aquest treball sobre el cos el que crea o fabrica el subjecte mateix. En aquest sentit, el camp de la subjectivitat es configura com un efecte de l'aplicació dels dispositius disciplinaris; altrament dit, com un efecte de les relacions de poder que permet i prioritza un diagrama concret, en aquest cas, el diagrama disciplinari.

La disciplina es desplega en el camp social a través dels diferents dispositius disciplinaris, tot seguint una multiplicitat de dinàmiques que es poden englobar en quatre grans blocs:

a) La distribució dels individus en l'espai: "la disciplina —assenyala Foucault - exigeix a vegades la clausura, l'especificació d'un lloc heterogeni a tota la resta i tancat sobre ell mateix". Això es fa palès a la distribució arquitectònica dels dispositius disciplinaris, com ara els col-legis, els internats, les casernes, les fabriques, els convents, les fortaleses i, de forma paradigmàtica, el Panòptic — concebut per Bentham — com a exemple principal de la institució carcerària i forma prototípica del diagrama disciplinari — no debades, Foucault considera l'era de la disciplina com l'era del panoptisme -.$^{14}$

b) Aquesta distribució espacial afavoreix l'aglomeració interessada de les multiplicitats d'individus, que fins llavors romanien espargides i difuminades, tot impedint així un altre tipus d'aglomeracions (no interessades) que pogueren derivar, per exemple, en qualsevol tipus de revoltes. El règim disciplinari esdevé, així, una manera de facilitar, al mateix temps, la vigilància, el control, la medició i, finalment, l'ordenació i la classificació jeràrquica de les conductes.

c) La distribució temporal, heretada de les primeres formes de disciplina que es remunten als règims monàstics; això és: establiment dels ritmes, regulació dels cicles de repetició, confecció d'uns horaris estrictes que han de garantir una dedicació completa i un aprofitament exhaustiu del temps que desemboquen en un rendiment garantit; en paral-lel, els endarreriments, les absències i les interrupcions de l'activitat són corresponentment penalitzats.

14 "El Panòptic (...) és una categoria de poder, pura funció disciplinària. Per tant, Foucault l'anomenarà diagrama, funció que 'cal desvincular de tot ús específic', i també de tota substància especificada” (Deleuze 1986, 87). 
d) Una composició i una estructuració de les forces implicades que resulte altament eficaç per al dispositiu disciplinari. En efecte, aquesta ordenació, que respon a una estratègia determinada, ha de suposar un augment de la força resultant final. Es tracta d'una dinàmica que prové de la disciplina militar, però que acabarà estenent-se per tots els dispositius disciplinaris i pel diagrama que els acull.

Segons Foucault, les relacions de poder disciplinàries — aquelles que formen el diagrama disciplinari- cristal-litzen en una sèrie d'institucions que perviuen en l'actualitat; institucions com ara les escolars-educatives, les mèdiques-sanitàries, les militars i, per descomptat, les penitenciàries. ${ }^{15}$ En aquest sentit, tot i que Foucault no analitza aquests dispositius des del punt de vista històric, més enllà del fet de circumscriure'ls a l'època clàssica, com ja hem vist —si més no a la seua obra principal sobre la qüestió Surveiller et punir, de l'any 1975 -,${ }^{16}$ es poden resseguir algunes indicacions als cursos que va impartir al Collège de France, la publicació tardana dels quals —actualment encara n'estan eixint a la llum - va anar obrint la porta, a partir de 1997, a una nova generació de lectors que van poder esclarir alguns conceptes concrets de la seua obra i aproximar-se a alguns dels seus passatges amb una perspectiva més acurada. Entre aquestos conceptes es troba, sens dubte, la disposició triangular dels diagrames, que va substituir la concepció historiogràfica que proposava una substitució successiva dels mateixos. ${ }^{17}$

Tot i que és als segles XVII i XVIII quan comencen a expandir-se els dispositius del diagrama disciplinari, fins abastar amb el seu focus la totalitat del camp social, ja es pot detectar la seua influència durant el període anterior presidit pel diagrama de sobirania; de la mateixa manera, aquests es conservaran posteriorment, una vegada el focus haja passat a il.luminar el diagrama biopolític. ${ }^{18}$ Segons una visualització gràfica, proposada pel propi Foucault, tot

15 "El sistema penal és la forma en la qual el poder es mostra més manifestament com a poder. Clavar a algú a la presó, mantenir-lo pres, privar-lo d'aliment, de calefacció, impedir-li eixir, fer l'amor, etcètera, és la manifestació de poder més delirant que puga imaginar-se. (...) La carcel és l'únic entorn en el qual el poder gosa manifestar-se un en les seues dimensions més excessives, tot justificant-se com a poder moral" (Deleuze 2005, 270).

16 "No es tracta de fer ací la història de les diferents institucions disciplinàries (...) sinó d'assenyalar algunes de les tècniques essencials que s'han generalitzat" (Foucault 1975).

${ }^{17}$ Aquesta concepció triangular dels diagrames es va esclarir sobretot al curs Seguridad, territorio y población, que no va veure la llum fins l'any 2004 a França i fins l'any 2008 a Espanya.

${ }^{18}$ Efectivament, aquests són els tres principals diagrames analitzats per Foucault. Així assenyalava Deleuze les principals diferències entre els diagrames de la sobirania i de la disciplina, respectivament (el diagrama biopolític s'analitzarà detingudament al següent punt): "Quan Foucault invoca el concepte de diagrama, ho fa en relació amb les nostres societats modernes de disciplina, on el poder fa un quadriculat de tot el camp (...) Però, quan es consideren les antigues 
ocorre com si la disposició del camp social es donara de forma triangular, de manera que cadascun dels vèrtex corresponguera a cadascun dels tres diagrames estudiats:

És precís comprendre les coses no com el reemplaçament d'una societat de sobirania per una societat de disciplina i després d'una societat de disciplina per una societat (...) de govern. De fet, estem davant un triangle: sobirania, disciplina i gestió governamental (FoucAult 2006, 135)

Caldria pensar, així, en una mena de joc lumínic per entendre la preponderància de cadascun dels diagrames en un moment donat. D'aquesta manera, es pot il.luminar el vèrtex corresponent a la sobirania fins al punt d'inundar la totalitat del camp social. Això, però, no vol dir que encara no hi haja cap dispositiu disciplinari o biopolític; aquests existeixen —Foucault considera les comunitats monàstiques, per exemple, els primers dispositius disciplinaris-, tot i que, pel moment, no s'articulen de manera efectiva en l'entramat que compon el diagrama.

Pel mateix, quan li arriba el torn al vèrtex de la disciplina, els dispositius de la sobirania no desapareixen; al contrari, la majoria de les vegades són absorbits pels dispositius disciplinaris — com ocorre, per exemple, amb la ideologia del dret i els codis jurídics del segle xIx, inspirats en teories eminentment relacionades amb la sobirania. El mateix es pot dir pel que fa a la posterior il.luminació del vèrtex de la biopolítica.

Des d'aquest punt de vista, podem comprendre millor com la història de la disciplina es remunta al diagrama de la sobirania i es perllonga fins al de la biopolítica. Una història que Foucault estableix al llarg d'una sèrie de fites:

1. Les comunitats religioses de l'Edat Mitjana — dispositius disciplinaris al si del diagrama de la sobirania, com acabem de dir-.

2. Inici de l'expansió i generalització, al segle XvII, de les disciplines a través de l'extrapolació del règim monàstic a les dinàmiques educatives —a través, sobretot, de l'organització paramilitar dels Germans de la Vida Comuna-.

3. Disciplinarització, també als segles XVII i XvıII, d'altres dispositius com ara l'hospital, la caserna i la fabrica. Aquesta proliferació respon a la progressiva incapacitat del diagrama sobirà per respondre a les exigències disciplinàries de l'expansió i el desenvolupament industrial.

societats de sobirania, es veu que no els falten els diagrames, encara que es tracti d'unes altres matèries i unes altres funcions: també hi ha una força que actua sobre d'altres forces, però més aviat per sostreure que no pas per combinar i compondre; per dividir masses més que no pas per perfilar el detall; per exiliar i no pas per quadricular" (Deleuze 1986, 46-7). 
4. Instauració del diagrama disciplinari: reforma del codi penal entre els anys 1760 i 1840 i formalització de la microfísica del poder disciplinari al Panòptic de Bentham (1787).

5. Per últim, de la mateixa forma que les comunitats monàstiques ja existien com a dispositius disciplinaris al si del diagrama de la sobirania, la família roman com a dispositiu sobirà al si del diagrama disciplinari. Així es pot observar en la seua estructura patriarcal, fundada en el llinatge i l'ascendència, però també en les diferents relacions de contracte, propietat i compromís que es desenvolupen al seu si. (Com veurem al següent punt, la família és un cas molt especial ja que, a més de romandre com un reducte sobirà al si del diagrama disciplinari — complint un paper molt essencial en aquest diagrama-, servirà de frontissa, al mateix temps, per a l'expansió del diagrama de la biopolítica.)

\section{EL NAIXEMENT DE LA BIOPOLÍTICA: UN NOU DIAGRAMA DE PODER}

Durant la segona meitat del segle XviII, però sobretot amb la fi de l'absolutisme al segle xIx, emergeix una tecnologia del poder que ja no es dirigeix tant a la superfície del cos com a la vida mateixa; que ja no individualitza la multiplicitat, sinó que es dirigeix, més bé, a la multiplicitat en tant que massa global; al cap i a la fi, que ja no és tant una anatomopolitica al voltant del cos humà, com una biopolítica al voltant de l'ésser humà en tant que espècie. Cal matisar, però, que l'anatomopolítica i la biopolítica no són sinó dues aplicacions o dues direccions en les quals es desplega un mateix biopoder o poder sobre la vida. No es tracta, per tant, de nocions antitètiques, sinó que estan travessades per un munt de relacions. De fet, serà la medicina — junt al marc normatiu o legal i la família—, una de les frontisses entre ambdues tecnologies, la disciplinària i la biopolítica, en la mesura que aquesta, la medicina, estarà dirigida, simultàniament, a l'organisme en tant que cos i a la població-massa com a principal objecte biopolític de coneixement i control. ${ }^{19}$ Això es produeix, sobretot, a través de les diferents qüestions tractades pels sabers-frontissa que es generen al voltant del sexe: la natalitat, la precocitat, la freqüència de les relacions sexuals, la fecunditat, l'esterilitat, el celibat, l'anticoncepció,

\footnotetext{
${ }^{19}$ Foucault arriba a referir-se a la biopolítica com una "somatocràcia": "En l'actualitat està sorgint el que en realitat ja es venia preparant des del segle XviII, és a dir, (...) una somatocràcia. Vivim a un règim en el qual una de les finalitats de la intervenció estatal és la cura del cos, la salut corporal, la relació entre la malaltia i la salut" (Foucault I999, 346).
} 
etcètera. ${ }^{20}{ }^{\prime}$ 'illlumina, d'aquesta manera, el vèrtex de la biopolítica, tot posant el focus del control i el saber —és a dir, el focus del saber-poder- sobre els processos vitals de l'espècie humana, relacionats amb la vida, la mort $i$, per tant, també amb la salut (natalitat, fecunditat, reproducció, mortalitat, demografia, salubritat, vivenda...). En definitiva, quan parlem de biopolítica ens referim a tots aquells processos que, des de la perspectiva de les relacions de poder, afecten a la població en sentit ampli, que al llarg d'aquest segle apareix com un nou subjecte - i objecte- polític.

Així doncs, si una de les característiques de la disciplina era la composició de les forces per assolir la major eficàcia possible d'un dispositiu concret, la biopolítica vetllarà pel manteniment de la vitalitat del conjunt de la població, per exemple esperonant a la higiene mitjançant campanyes sistemàtiques de conscienciació mèdica. A través de la biopolítica, el poder s'encarregarà de controlar, tot mesurant i quantificant mitjançant estimacions estadístiques —ací rau, de fet, l'origen etimològic de la paraula: l'estadística com a ciència de l'Estat-, una sèrie de fenòmens naturals per, tot seguit, tractar de modificar els resultats o, en qualsevol cas, pal-liar els seus efectes. Es tracta, al capdavall, de "modificar i reduir la mortalitat", d'"allargar la vida" o d'“estimular la natalitat" (Foucault 2008A, 223).

En aquest sentit, durant el curs de 1978 Foucault anomena dispositius de seguretat els dispositius propis del diagrama biopolític. Per aquest costat, s'estableixen una sèrie de diferències essencials entre aquests dispositius i els de tipus disciplinari. Mentre que en el cas dels dispositius disciplinaris ens trobem davant una reglamentació exhaustiva de tot l'espai social, fonamentada en la prescripció i en la prohibició del que és legal i el que és il-legal respectivament, els dispositius de seguretat es basen, en canvi, en un deixar fer observador i relativament distant dels esdeveniments econòmics i socials. Sense oblidar, però, que cal exercir un control per evitar els possibles —i perillosos - desenvolupaments inesperats inherents a la lliure circulació a la qual els nous mecanismes de dominació hi donen cabuda (Foucault 2006, 69). ${ }^{21}$ Aquest procediment no es pot basar, per tant, en una imposició prohibitiva, implacable i contundent com la de la sobirania, sinó, al contrari, en una subtil delimitació dels fenòmens socials i econòmics, és a dir, en una mínima intervenció adreçada a endegar els fenòmens.

20 "El sexe (...) es troba a la cruilla dels dos eixos al llarg dels quals es va desenvolupar tota la tecnologia política de la vida (...) És a la vegada accés a la vida del cos i a la vida de l'espècie. És emprat com a matriu de les disciplines i com a principi de les regulacions" (Foucault i976, 176).

${ }^{21}$ L'anàlisi d'aquesta dinàmica paradoxal recorda a l'anàlisi que efectuen Deleuze i Guattari a Capitalisme i Esquizofrènia, en termes de processos de desterritorializació i reterritorialització com inherents a la dinàmica capitalista. 
Aquest deixar fer remet, inevitablement, al laissez faire propi del liberalisme. Aquesta és una de les caracteritzacions que podem relacionar amb el primer estadi de la biopolítica: deixar que les coses passen segons el transcurs dels esdeveniments; que la realitat es desenvolupe segons les seues pròpies lleis; que les persones i el capital circulen lliurement per tot el mapa social. Els dispositius de seguretat de la biopolítica estan, per aquest costat, íntimament lligats al desenvolupament original del sistema capitalista i als plantejaments teòrics que li atribueixen la seua legitimitat:

Aquest bio-poder va ser, sens dubte, un element indispensable en el desenvolupament del capitalisme, que no es va poder afirmar sinó al preu de la inserció controlada dels cossos en l'aparell de producció i mitjançant un ajustament dels fenòmens de població als processos econòmics (Foucault 1976, 170)

Ara bé, al si de la biopolítica aquest liberalisme es tradueix en una extensió dels mecanismes de control; el que comporta, al seu torn, un desbordament dels mecanismes de vigilància, a través dels quals es feia efectiu el poder disciplinari. Mentre que al diagrama disciplinari la vigilància era un contrapès de la llibertat, una conseqüència indefugible d'aquesta, en el cas del diagrama biopolític s'estimben aquests límits i és el control mateix, com a mesura coercitiva, el que esdevé la condició de possibilitat de la llibertat. En aquest sentit, el laissez faire o la mínima intervenció del govern no implica sinó una major precisió $i$, en definitiva, uns dispositius de control més subtils i més eficients que els que hom havia posat en funcionament adés. En efecte, per detectar el moment precís en què cal intervenir sobre el transcurs natural dels esdeveniments, s'acaba tenint un coneixement exhaustiu i un control detallat de l'entorn i el context en què aquests es donen:

Aparició, també en aquest nou art de governar, de mecanismes la funció dels quals consisteix a produir, insuflar, incrementar les llibertats, introduir un plus de llibertat mitjançant un plus de control i intervenció. És a dir, que en aquest cas el control ja no es limita a ser, com en el cas del panoptisme, el contrapès necessari a la llibertat. És el seu principi motor (FouCAULt 2008B, 89)

Això és el que Foucault analitza mitjançant el concepte de governabilitat. Segons aquest model, el govern ha de vetllar per garantir la major generació de riqueses per part de la població $i$, en conseqüència, pel seu corresponent avituallament, garantint així també, per una altra part, la seua reproducció. D'aquesta manera, s'inverteixen els termes en els quals s'entenia la relació de vassallatge en els règims de sobirania. Mentre que en aquells règims el sobirà 
havia d'actuar com si, efectivament, tots els seus súbdits estigueren al seu servei, sempre i de manera incondicional, en aquest nou model és el governant el que ha d'actuar com si estiguera al servei de la població — de la mateixa forma que el pare, en haver de vetllar per la casa, està al servei de la seua famíliaI si el blanc d'aquesta governabilitat és, com hem vist, la població, i el seu instrument tècnic essencial els dispositius de seguretat, la seua forma de saber principal esdevé l'economia politica, que es presenta com un saber que té com objectiu garantir l'enriquiment constant de l'Estat, mitjançant un equilibri entre, per una banda, la població i, per l'altra, els articles de subsistència.

Aquesta nova noció de governabilitat afegeix un nou enfocament pel que fa a la concepció foucaultiana del poder: el poder ja no és concebut com una lluita de forces o, directament, com una guerra — l'anomenada "hipòtesi $\mathrm{Ni}$ etzsche”-, sinó com una influència directa en les conductes dels altres:

El poder, en el fons, és menys de l'ordre de l'enfrontament entre dos adversaris o del compromís d'un front a l'altre que de l'ordre del govern. El mode de relació propi del poder no caldria buscar-lo, doncs, pel costat de la violència i de la lluita ni pel costat del contracte o del nexe voluntari (...) sinó pel costat d'aquest mode d'acció singular, ni guerrer ni jurídic, que és el govern ${ }^{22}$

Seguint en aquesta línia, arribem al que exposa Foucault al final de Naissance de la biopolitique. De manera excepcional, durant el transcurs d'aquest curs que imparteix al llarg de l'any 1979, Foucault aplica la seua anàlisi a la situació contemporània. Així, exposa com l'extensió del control pròpia del liberalisme - i, per tant, de la biopolítica — acaba degenerant, en el cas del neoliberalisme nord-americà, en una colonització, per part dels codis econòmics i de la lògica mercantil, de la totalitat del camp social. D'aquesta manera, en un moviment anàleg i simultani a aquell altre moviment que hem enunciat, a través del qual el control acabava estenent-se per tot el camp social i esdevenint condició de possibilitat de la llibertat, les lleis del mercat i el llenguatge financer s'estenen també arreu de la societat, per acabar esdevenint la possibilitat de desxiframent i descodificació d'unes relacions socials i d'uns comportaments individuals exclusivament basats en la nova concepció del lliure mercat.

${ }^{22}$ Michel Foucault, Dits et Écrits IV (CASTro, 20 I I, 237). 


\section{Conclusió}

Hem vist com Foucault fa servir l'eixamplament de les pràctiques punitives a l'època clàssica — d'un esdeveniment únic i espectacular a una multiplicitat de pràctiques de coerció- per exposar, també, com es produeix l'eixamplament del poder d'aquella entitat transcendent de l'època de la sobirania, a una multiplicitat de relacions de poder espargides arreu del camp social. És durant aquesta època — que Foucault anomena l'època de la disciplina- que la capillaritat del poder es mostra en la seua màxima esplendor. Això serveix Foucault per explicar les característiques essencials del poder i per posar de manifest el fet que aquestes característiques ja eren presents al diagrama precedent, el de la sobirania - a través, per exemple, de les lettres de cachet en les quals els mateixos súbdits demanaven la intervenció del rei en diferents plets i acusacions quotidianes-, així com en el diagrama posterior, pròpiament biopolític —anomenat societat de control per Deleuze-, que arriba fins els nostres dies.

A falta d'una vessant explícitament prescriptiva en la filosofia de Foucault —en una entrevista amb Noam Chomsky arriba a afirmar que no és "capaç de definir, i molt menys de proposar, un model de funcionament social ideal per a la nostra societat" (Foucault I999, 83)—, podríem fer una interpretació eminentment immobilista de la seua filosofia. Tot atenent al caràcter immanent que Foucault atorga al poder, segons la qual és el camp social sencer el que està travessat per les relacions de forces establertes - hom podria afirmar, en efecte, que no hi ha escapatòria possible. ${ }^{23} \mathrm{D}$ 'aquesta forma, però, estaríem incorrent en la concepció negativa del poder que, com hem vist, compartien els contractualistes i els juristes amb els paramarxistes. ${ }^{24}$ El que pretén posar de manifest la concepció foucaultiana, en canvi, és la positivitat d'un poder que, precisament, pel fet d'impregnar-ho tot i travessar totes les relacions del camp social — relacions que, en la mesura que estan composades per dos pols son, per definició, reversibles - es mostra, precisament, més susceptible al canvi que no en teories polítiques més tradicionals —aquelles teories que incorrien en els

${ }^{23}$ Aquestes crítiques han sigut efectivament realitzades, com remarca Mark Poster: "Si el poder està a tot arreu, al-leguen els crítics, les perspectives de democratització son molt tènues. L'anàlisi de Foucault, d'acord amb aquesta crítica, condueix a un pessimisme o quietisme, una espècie de posició apolítica, que és la reivindicada pels 'nous filòsofs' més notoris" (Poster I 984 [1987], 217).

${ }^{24}$ Així és com es refereix Foucault als representants de l'anomenat "marxisme occidental": "Si el marxisme occidental va sorgir com una resposta teòrica als obstacles que es va trobar el marxisme clàssic a l'enfrontar-se als esdeveniments que van des de la Primera Guerra Mundial a la Guerra Freda, els llibres recents de Foucault poden avaluar-se com una resposta teòrica a les dificultats del marxisme occidental per interpretar les rebel-lions de la dècada de 1960 i la nova formació social sorgida posteriorment" (PosTeR I984 [1987], 13). 
postulats que Deleuze anomenava de possessió i de localització. Amb això, lluny de convidar a l'immobilisme, la filosofia de Foucault mostra com de pròxima es troba la possibilitat de canvi, tot i que aquest requerisca una tasca molt més profunda i precisa que la que proposen aquells plantejaments teòrics per als quals el poder està en possessió d'un individu o d'una sèrie d'individus, en un lloc determinat i, per tant, resulta inabastable per a la resta del conjunt social.

Fet i fet, si tenim en compte les característiques que Foucault li atorga al poder, arribem a la conclusió que no es pot pretendre un enfrontament amb l'Estat — com el lloc on situar el monopoli de la força o de les relacions de poder-, des de la perspectiva d'un programa a través del qual arribar al poder o, simplement, com una forma de reformar les estructures establertes. A més a més, aquesta pretensió requeriria l'elaboració d'un partit com a estructura orgànica, definit per unes dinàmiques similars a les que es troben en l'interior de l'Estat - la presa del poder requereix, per aquesta part, un acoblament o una analogia entre les formes de poder-. Tot plegat, comportaria una concepció de tipus macro-politic del tot allunyada del plantejament foucaultià:

Per poder lluitar contra un Estat que no és solament un govern, és necessari que el moviment revolucionari es procure l'equivalent en termes de forces políticomilitars, en conseqüència, que es constitueixca com a partit, modelat —en l'interior- com un aparell d'Estat, amb els mateixos mecanismes de disciplina, les mateixes jerarquies, la mateixa organització de poders ${ }^{25}$

En efecte, les dinàmiques del poder que hem descrit, és a dir, l'existència d'aquest poder de tipus immanent que s'estén pel camp social de manera capil.lar, exigeix abans que res l'elaboració d'una anàlisi micro-política — d'una microfísica del poder-. Aquesta és la condició de possibilitat, pel costat teòric, per a una tasca posterior d'erosió interna, adreçada a modificar des de baix les relacions sobre les quals s'erigeixen les estructures del poder. D'aquesta manera, es poden acabar modulant els dos principals efectes que produeix el poder, les seues dues principals cristal-litzacions: per una part, l'estratègia diagramàtica de constitució del camp social, amb les seues institucions; per una altra, la producció de subjectivitat, com una de les eines principals a través de les quals fa efectiva la seua influència. Per aquest costat, tot i que Foucault, com hem vist, nega de bestreta qualsevol interpretació prescriptiva que es puga fer de la seua microfísica del poder —adreçada a assolir uns objectius pràctics en clau col-lectiva-, pot servir, nogensmenys, com a punt de partida d'una revolució microfisica — en la línia del que Deleuze i Guattari anomenen la revolució

${ }^{25}$ Michel Foucault: Poder-cuerpo (entrevista a la revista Quel Corps) (Foucault I992, 107). 
molecular. Des d'aquesta perspectiva, si finalment els moviments de resistència es tradueixen en una revolució a major escala, al nivell d'una ruptura amb el mode de producció existent i amb els seus instruments de reproducció, seria, en qualsevol cas, com a efecte d'una multiplicitat de micro-revolucions disseminades arreu del camp social:

Així com la xarxa de les relacions de poder acaba construint un espès teixit que travessa els aparells i les institucions sense localitzar-se exactament en ells, així també la formació de l'eixam dels punts de resistència solca les estratificacions socials i les unitats individuals. I és sens dubte la codificació estratègica d'aquestos punts de resistència el que torna possible una revolució, un poc com l'Estat reposa en la integració institucional de les relacions de poder (FouCAULT 1976, 117)

Per últim, l'anàlisi que realitza Foucault del neoliberalisme nord-americà presenta una enorme capacitat d'anticipació. Cal tenir en compte que el porta a terme al llarg del curs de 1978-1979, tot just quan el neoliberalisme, tal i com és conegut en l'actualitat, feia les seues primeres passes decidides als Estats Units. Aquests processos que va detectar Foucault en referència al desbordament dels codis financers vers la totalitat del camp social han abastat, trenta anys després, una acceleració exponencial, que els ha conduït fins la seua màxima expressió. Aquesta acceleració ha provocat, al seu torn, molts efectes pel que fa a la constitució de les subjectivitats contemporànies, que han acabat d'interioritzar al seu si les lògiques capitalistes emanades de la intensificació dels dispositius biopolítics.

En aquest sentit, ja no es pot concebre la resistència en termes dels drets que cal assolir per part d'un subjecte impermeable a un poder transcendent. Parlar de resistència, avui dia, és parlar de creació de subjectivitat. No podem resistir el poder amb la subjectivitat que ens és donada, atenent que aquesta té el seu historial de creació, precisament, en les pròpies relacions de poder.

Per aquesta part, les anàlisis marxistes tradicionals semblen quedar obsoletes o, almenys, inservibles per a les noves formes més subtils, difuses i disperses que presenta el biopoder. No ocorre el mateix amb les anàlisis neo-marxistes, com ara les de Michael Hardt i Antonio Negri que, tot prenent com a referent les anàlisis micropolítiques de Foucault, apliquen la seua formulació del dispositiu a l'emergència d'un procés constituent. D'aquesta manera, veuen en els "dispositius de producció de subjectivitat" (Hardt i Negri 20 I2, 52) (amb la seua respectiva regla de condicionament o de causa immanent) l'única alternativa a la producció del capitalisme avançat. La construcció de noves subjectivitats, tal i com la va concebre Foucault, esdevé, des d'aquest punt de vista, la principal possibilitat de resistència davant l'augment, la profunditat i la precisió que ha assolit la producció capitalista en l'actualitat. 


\section{BiBLIOGRAFÍA}

Castro, E. 20 i i, El vocabulario de Michel Foucault, Buenos Aires: Siglo XXI.

Deleuze, G. 1986, Foucault, Barcelona: Edicions 62.

Deleuze, G. 2005, La isla desierta y otros textos. Textos y entrevistas (1953-1974), València: Pre-Textos.

Deleuze, G. 2007, Dos regímenes de locos. Textos y entrevistas (1975-1995), València: Pre-Textos.

Foucault, M. 1975, Vigilar y Castigar. Nacimiento de la prisión, Madrid: Siglo XXI.

Foucault, M. 1976, Historia de la sexualidad 1: La voluntad de saber, Madrid/ Buenos Aires/Mèxic DF: Siglo XXI.

Foucault, M. 1992, Microfisica del poder, Madrid: La Piqueta.

Foucault, M. 1999, Estrategias de poder (Obras esenciales, volumen II), Barcelona/ Buenos Aires: Paidós.

Foucault, M. 2005, El poder psiquiátrico: curso del Collège de France, Buenos Aires: Fondo de Cultura Económica.

Foucault, M. 2006, Seguridad, territorio, población. Curso en el Collège de France, Buenos Aires: Fondo de Cultura Económica.

Foucault, M. 2008A, Hay que defender la sociedad. Curso en el Collège de France, Buenos Aires: Fondo de Cultura Económica.

Foucault, M. 2008в, Nacimiento de la biopolítica. Curso en el Collège de France, Buenos Aires: Fondo de Cultura Económica.

Giraldo Díaz, R. 2006, "Poder y resistencia en Michel Foucault", Tabula Rasa, 4: 103-22.

Hardt, M. i Negri, A. 20 i2, Declaración, Madrid: Akal.

Poster, M. I984, Foucault, Marxismo e Historia: Modo de producción versus Modo de información, Buenos Aires/Barcelona/Mèxic DF: Paidós [1987]. 